\title{
Witchcraft or Spiritual Power among Bajju Christians
}

\author{
Carol V. McKinney
}

\begin{abstract}
The Bajju in Northern Nigeria believe in an inherent inherited capacity for the use of spiritual power, also termed witchcraft, that results in illnesses, misfortune, evil, and death in the physical realm. This article explores this system, including indications that an individual is practicing witchcraft and the assumptions behind this conceptual system. It is a system that some Bajju Christians are seeking to Christianize by asserting that it is an evil spirit or evil spirits that can enter a person whose own spirit then leaves his or her body to meet with other spirits in the spiritual realm, resulting in dire consequences for someone in the physical realm. Thus, witchcraft is used to explain evil even among Christians. I suggest that a more biblical understanding of evil, rooted in a mother tongue translation of the Bible, is needed to prepare Christians to take responsibility for their own behavior and to properly attribute evil to Satan, the father of lies. ${ }^{1}$
\end{abstract}

\section{Introduction}

Evans-Pritchard, a British social anthropologist, termed the use of spiritual power as "witchcraft" (1976). Though his research was among the Azande in Southern Sudan, Central African Republic, and northern Democratic Republic of Congo, this conceptual system is widespread throughout SubSaharan Africa. He defined witchcraft as "a supposed psychic emanation from witchcraft-substance which is believed to cause injury to health and property" (1976:226). Offiong similarly states "witchcraft is the psychic act through which socially disapproved supernatural techniques influence events ..." (Offiong 1985:153).

The Bajju, ${ }^{2}$ who live in southern Kaduna State, Nigeria, West Africa, believe that individuals are born with an inherent inherited capacity to use spiritual power through psychic emanations to harm others in the spiritual realm which results in evil, misfortune, illness, or death in the physical realm. Bajju assert that some people are born without this power, but later acquire it. Use of spiritual power is a psychic act; it involves no rites, spells, sorcery, or medicine.

My first encounter with what the Bajju term nkut came when talking with Ishaku, a young man who helped around our house. One day when he returned from his lunch break, he told me about something that had happened in the "empirical." I had no clue what he was talking about, and he was bewildered by my ignorance concerning the empirical realm. Later, after we began living in a Bajju village, and as I learned more about their beliefs, I found that the Bajju speak of witches meeting together in a kind of meat market in the spiritual realm. In time it dawned on me that Ishaku was talking about what Evans-Pritchard had termed witchcraft. Gradually an entire conceptual system emerged in which occurrences, such as automobile and motorcycle accidents, deaths of all except of elderly persons, socially unacceptable behavior, most illnesses, and other misfortunes were all attributed to nkut. The longer my husband and I lived with the Bajju, the more

\footnotetext{
${ }^{1}$ I wish to thank the Sociology Department of Ahmadu Bello University for granting me a research associateship for this research. I also thank the Summer Institute of Linguistics and my deceased mother for funding this research. My thanks go to Sam Waje Kunhiyop who worked with me in data collection, and to the late Musa Asake who reviewed this article for accuracy. My gratitude goes to my family too. Susan and Christy, our daughters, accompanied me to Nigeria and helped make it possible for me to collect data. My sons, Mark and Eric, remained in the U.S. keeping the "home fires burning." Finally, my profound gratitude goes to my late husband, Norris, who assisted me immeasurably with this research and paper. An earlier version of this paper was presented at the Evangelical Missiological Society conference, Deerfield, Ill. Feb. 26, 2011.

2 The Bajju have been referred to as the Kaje in the literature and by outsiders. The Bajju speak the Jju language, and they live in Kajju. The term Kajju is probably the origin of the term Kaje. Another possible source of the word Kaje is that it comes from kazwu, which refers to a particular cleared area that is ready for construction of a house or granary (Asake 1991:4).
} 
areas of life we found in which nkut or witchcraft was involved.

Nkut deals with the question of why misfortunes happen to specific individuals at particular times and places, with fractured social relations, and with what Evans-Pritchard termed "socially relevant causes" (1976:73). Kluckhohn (1967:83-84) similarly believed that at the psychological level witchcraft was an outlet for hostility between individuals. Explanations of events attributed to use of spiritual power do not invalidate immediate physical causes, but rather supplement them. Wilson (1971:35) identified witchcraft as the social metaphor for innate evil. She stated of the Nyakyusa of Tanzania that, "Brooding anger in the heart was thought to be the root of witchcraft" (1971:36).

In many societies there are separate words for sorcery, the use of magic for evil purposes, and for witchcraft. In other societies these two concepts blend together with a single word encompassing both concepts. Among the Bajju if sorcery or miracles occur, the phrase nkyang mamaki is used, which literally translates as "things of wonder." Bajju distinguish two types of nkut: good nkut (ätsatsak nkut) and evil nkut (abibyyi nkut or akatuk nkut). Good nkut is protective discernment. For example, while drunk late one night one man came to the compound where his sister lived. Her husband met him and refused to allow him to enter their compound because he believed that his brotherin-law's coming was for evil purposes. He stated, "I know why you have come. You have come to harm my wife, but I won't let you. Go to your own house which is over there." A couple of months later the brother-inlaw's daughter died. His sister's husband said, "Aha, didn't I tell you that he had come for evil purposes? But I wouldn't allow him to enter my house, so he carried out his evil purposes within his own house." This man claimed that he had the ability to see in the spiritual realm such that he discerned the evil intent of his brother-in-law and had used that knowledge to protect his family.

To the Bajju no death is due to natural causes other than the deaths of elderly individuals who have fulfilled their roles and functions in life. As Mbiti states,

There are always physical causes and circumstances surrounding every death. These include sickness, disease, old age, accident, lightning, earthquake, flood, drowning, animal attack, and many others. But African peoples believe that a particular person will only die from one of these physical causes because some human or other agent has brought it about by means of a curse, witchcraft, magic and so on. These are what we may call the mystical causes of death (Mbiti 1975:112).

\section{A Bajju Case Study}

While driving in Kaduna, an expatriate struck a Bajju young man who was crossing the street and killed him. The police soon came and asked the driver what had happened. He replied that he saw a cat in front of the car; he had not seen a man. This explanation communicated to the Bajju that this was an example of the use of spiritual power (witchcraft). The Bajju believe that an individual with spiritual power may on occasion transform him or herself into an animal or enter the body of an animal. The fact that an expatriate stated that he saw a cat, and that Bajju tend to ascribe honesty to expatriates, confirmed to the local people that nkut was involved.

When Bajju suspect that someone is responsible for a particular death, those who attend the funeral are asked to swear that they are not responsible for this death. This practice is known as tun kanu rwak, also termed sswa mbyen, to swear on the dirt by stating, "I am not responsible for this death. If I am responsible, may I follow this person in death." This is followed by beating one's hand on the ground. Christians often ask to swear on the Bible rather than on the ground and this is acceptable. Some individuals may refuse to swear because of the consequences that might befall them and their families with death following down through the generations until someone repents. However, normally people go ahead and swear. Bajju believe that after they have sworn the truth will show up and the consequences of having sworn falsely will occur. Traditionally, nkut accusations were against members of an individual's patrilineage (Kato 1973:219-222).

In this example of the young man who died in the automobile accident, and because the expatriate said he had seen a cat, the death of the young man was attributed to nkut. At the funeral each person who attended was asked to swear on the dirt of the grave that he or she was not responsible in the spiritual realm for this death. In this instance the deceased man's father refused to swear because he believed that this custom was nonsense. Consequently, people accused him of having killed his own son by nkut.

The deceased's sister, wanting to escape having something similar happen to her, returned to the Bajju home area and stayed there for a month. When she returned to Kaduna, after visiting her brother's grave and while crossing the street, she too was hit by a car and killed. Again, some Bajju accused her father of causing the deaths of both of his children. By this time the father was reduced to talking nonsense, which was further evidence to the Bajju that he was responsible for both of their deaths. 


\section{Nkut and the Life Cycle}

Traditionally Bajju have viewed life as a circle that moves from birth to puberty to marriage to parenthood to old age and death, followed by rebirth through reincarnation. Bajju recognize this cycle in a number of ways. For example, a new male infant may receive a name such as Abrak meaning, "He has returned," referring to the reincarnation of an ancestor. Traditionally, and today within Christianity, death does not involve the extinction of an individual, rather his or her seed or spirit is still alive. Prior to the coming of Christianity, the ancestors were viewed as active in an underground world known as ayabyen. This was especially true for male elders who had lived to old age and who had fulfilled their prescribed roles on earth, including marrying, having children, and becoming respected elders in the community. Death is the transition from this world to the next world.

\section{$A$ meat market in the spiritual realm}

When an elderly person dies, people state, "They will eat tough meat tonight." This refers to the idea that those who practice nkut meet together in a meat market in the spiritual realm where meat is bought and sold; the meat is the flesh of the recently deceased. Those who practice nkut may eat the soul of an individual in the spirit realm, thus causing physical death.

Another example in which Bajju attributed death to nkut occurred following the celebration of a wedding. For the reception, the groom's parents killed a cow to serve their guests. When the groom's uncle was traveling to his home in the back of a pickup truck following his attendance at the wedding and reception, an accident occurred, and he fell from the truck and died. According to Bajju reasoning, when they killed the cow at the wedding, they were actually killing the uncle, whose spirit was in the cow. Professing Bajju Christians accused the groom's father and his father's brother of being responsible for this death (Kunhiyop 1988:51).

\section{Mosquitos and nkut}

When a person's psyche goes out at night it may eat mosquitos. Baju believe that when others are asleep the spirit in the mosquito may vomit into you by putting its mouth on you, and when doing so, draws out your blood. By this action, it can cause illness. The verb used for this action is nhyu, meaning "to press down." Bajju speak of "people who press down people" (banyet hyyu banyet) and thereby cause illnesses. In order to avoid this type of illness people sleep together. Again, if a person suspects that someone is pressing him or her down, that individual will seek to find out who is doing it in order to warn that person to cease.

\section{Eyes and nkut}

Bajju believe that all people, especially twins, are born with two sets of eyes: with one set they see things in the physical realm, and with the second nkut set they see things in the spiritual realm. They tell children to close their nkut eyes so that they will not harm others. Theoretically those who practice nkut have not closed their nkut eyes.

A person who practices nkut is termed a witch, an akut (bokut, pl.). People termed bokutatacciare usually blamed for illnesses. The word atacci means, "beyond the ordinary" or, "what is not seen with the eyes." These are people who operate in the spiritual realm. An zkut's spirit may leave his or her body at night when the person is asleep and inflicts harm or illness on another individual. In the past, persons blamed for use of spiritual power were warned to desist from such activities, perhaps beaten, expelled from the village, or for serious matters killed. On occasion a woman so accused will still be beaten and expelled from the village if $n k u t$ activities are attributed to her. When an akut dies, that individual is not given an honorable burial because the Bajju would not want that person to return through reincarnation.

\section{Children and nkut}

Bajju name their children according to events that occur around the time of their birth. Male infants born into families that have had children die in them may receive the name Bokut, meaning those who practice nkut, to indicate that even such people cannot harm this child. Similarly, a male infant may receive the name Nkut for the same reason. By so naming a child, the family is praying or asking the bakut to allow this child to live.

When children die within a compound, then someone is likely to be accused of causing their deaths through nkut activities. For example, people accused a former diviner of killing the children of her co-wife through her nkut activities. This accusation occurred when all the children of that co-wife died, and then her own children began to die as well. As a result, she was accused of being responsible for the deaths of her own children.

In another instance in a Christian family the two children of a young couple died. Members of this patrilocal patrilineal household urged the young wife to leave her husband and to return to her father's house because they believed her husband was responsible for the deaths of their two children through his nkut activities. So, she left and returned to her father's house. 
While there she had a dream in which a recently deceased Christian ancestor appeared to her. He urged her to return to her husband and told her that if she did not do so, when she died she would not find God. Consequently, she returned to her husband.

Traditionally, a diviner, an abvok, counseled an individual who had multiple children die to migrate to an urban environment to escape the nkut being practiced in the rural area. Sometimes people from urban environments migrate to the Bajju home area to escape nkut there. And sometimes people who live in urban environments, when they visit the home area, refrain from telling others that they are leaving in order to avoid nkut activities. In the past, migration as a means of avoiding nkut activities led fearful individuals to move frequently.

Some people believe that a person who is developmentally and physically disabled may be practicing nkut. In one instance a Christian pastor and his wife's fourth child was severely disabled. His disability was such that he could neither talk nor walk, but he moved around by scooting and recognized people who were in his everyday environment. His mother gave birth to two other children after him, each of whom died. While in the case of the disability of a child the parents are usually held responsible, in this case people reasoned that the disabled young man must have been the one responsible for the deaths of his two siblings. His abnormal behavior was evidence that he was an okut.

Traditionally, with children who were dwarfs, were mentally disabled or physically deformed, or who did not grow, thrive, walk, and talk within a reasonable period of time, the Bajju "returned them to the river" (drowned them) because they believed them to be river spirits. The cause of such an infant's condition might have been that something in the bush (kyang kayit, "a bush thing") fell on the mother when she was pregnant.

\section{Taboos Related to Nkut}

The Bajju have had a number of taboos related to nkut, some of which continue to be observed, such as the following:

1. People do not kill spirit snakes, snakes in which the spirit of a sleeping person or a person with a fever might have entered. If a person kills such a snake, the person whose spirit is in it will quickly be in agony and die. Types of spirit snakes are as follows:

a. A python (cong)

b. A particular type of snake, ccwak, that lives in mango trees

c. A large python type of snake that lives by the water (cencong, literally "river python”). A witch (əkut) may work in conjunction with this snake. Bajju believe that an əkut may take this snake into her house and give her children to the snake as food. In return the snake helps her become rich.

d. A cobra (angbaktssuk, literally a "rooster snake'). This snake is eaten only by diviners.

2. People must be careful concerning the source of the meat they eat. For this reason, Bajju tell their children to bring home any meat that they are given at another compound and not to eat it. The danger is that the meat they are given may have been obtained through someone's nkut activities. Bajju believe that if a person eats that type of meat, he or she may turn into a spirit (banyet ayabyen, "people of the underground world") who also engages in nkut activities.

3. Traditionally, women and children were not to eat eggs, chicken, birds in general, hyena, monkey, monitor lizard, and food prepared for the secret men's organization (the abvoi society). If a woman ate eggs, it meant that she would also "eat" (practice nkut against) her own children thus causing their illnesses and death. To do so would involve "eating" the eggs in her womb, thus leaving her barren.

As Evans-Pritchard indicated, the witchcraft system functions to project blame for misfortune on difficult or nonconforming individuals. Thus, it serves as a social control mechanism. Those who get out of line or who do not act according to the accepted cultural behavioral standards are apt to be accused. Among the Bajju, indications that an individual is involved in nkut activities include the following:

1. Staring at people at random. Traditionally Bajju do not look intently at someone while talking with them; one who practices nkut will stare at people directly.

2. Displaying characteristics opposite of friendliness, goodwill, generosity, civility, and qualities that maintain social unity. These are characteristics that Bajju esteem highly. Persons who do not display these qualities are apt to be accused of nkut because their spirits may be off working elsewhere while only their bodies are present.

3. Making life difficult for others and disturbing them.

4. Living alone. 


\section{Having multiple children die.}

6. Being disabled, though their parents or siblings are more apt to be accused.

7. Being elderly, including individuals of both sexes. Elderly individuals who have edema in their feet and legs due to cardio-vascular insufficiency are likely to be suspected of nkut activities. Swelling of the body is indicative of nkut.

8. A person who is widowed, remarried, and widowed again is suspected. This is especially true for women.

9. Being groggy. Since a person's spirit may leave his or her body during sleep, when a person first awakens and is not in complete command of his or her faculties, that person's spirit may not have completely reentered his or her body. The spirit may have been off working elsewhere doing nkut activities.

10. Not participating normally in conversations. It is as though that individual's spirit is not there within his or her body; the spirit is off working elsewhere. This includes students who may stare out of the window instead of paying attention to their teachers.

To a certain extent nkut has a capricious element to it. Individuals may not necessarily be aware that they are practicing $n k u t$, as when they stare randomly at people and do so using their nkut eyes. Yet, to deal with nkut Bajju elders warn people to refrain from engaging in it. They do so especially when a number of people have died, as when an epidemic comes to a particular area. Traditionally, first they prayed to the ancestors to intervene with God for them, then they warned people to desist from engaging in nkut activities. In investigating the Bajju concept of God, I found that it was very similar to the Christian concept of God. In fact, when translating the New Testament, we used the indigenous term Kaza for God. He is good and gives only good things, though he also judges people for their wrongdoings. It is precisely because he is good, that the Bajju do not attribute misfortune to him, but need some other explanation for evil which they offer through nkut accusations.

\section{Assumptions about Spiritual Power}

The system of witchcraft has its own internal logic based on widespread worldview assumptions. For example, Hill (1996:338-340) lists some basic assumptions about a witchcraft/spiritual power worldview, and provides explanations for them:
1. "A perfect world

Normal life is free from sickness, sterility, and death. Misfortune is unusual, intrusive.

\section{2. "Misfortune must be explained}

Misfortune does not occur randomly. It always has a specific cause and agent. Witchcraft explains misfortune.

\section{3. "Seeking revenge}

When the cause of misfortune is determined, revenge should be taken (in many cultures).

\section{4. "Do not talk about evil}

If people talk about witchcraft, they will be attacked.

\section{5. "Human beings as victims}

Human beings are the helpless victims of spirits and powers and have no control. Witchcraft . . . can use people without their consent.

6. "Fear

Life is full of fear of spiritual attack, or fear of being a witch.

\section{7. "Managing relationships through witchcraft accusations}

Hostilities in relationships are not resolved by direct confrontation, but by witchcraft accusations.

\section{8. "Group equality through jealousy}

An individual should not progress beyond the level of the group. This is not right and should be punished.

\section{9. "Kindness out of fear}

Fear of witchcraft accusations keeps people kind, on their toes and obedient.

\section{0. "Guilt projection}

Someone else is guilty for causing my problems, not me.”

To many in western cultures, sickness is viewed as coming from viruses, bacteria, retro-viruses, deterioration of organs due to the aging process, lack of sanitary conditions, contaminated water, etc. Further, accidents that result in injury and death are sufficient explanations. However, these are not sufficient causes for many Africans who recognize the immediate cause of a problem, but also feel the need to deal with the ultimate cause, namely the use of spiritual power which includes the socially relevant causes (for example, who is angry at whom). As one Bajju friend stated, "We 
know there is a lot of nkut being practiced. If that weren't so, why are so many of our young people dying in motorcycle and automobile accidents? The pastors need to warn the people to desist from such activities." The latter comment relates to the fact that traditionally diviners warned people to desist from these activities and pastors are now the spiritual leaders among the Bajju.

Belief in nkut enables Bajju to address the question of why there is evil in the world. It relates to their concept of God (Kaza) who is good. Since God is good and loving, he gives only good things such as fertility, rain, just judgment, and answers to prayer. He is not responsible for things that are evil other than that which comes because of his judgment and punishment on wrongdoers. Therefore, there must be some other explanation for the issues that nkut addresses. For example, death separates loved ones; therefore, Bajju consider it to be evil and the result of nkut.

\section{Christianity and Witchcraft Beliefs}

Each of the worldview assumptions mentioned by Hill (1996) needs to be examined in the light of what the Bible states from a Christian perspective. For example, from a biblical perspective the assumption that we live in a perfect world is inaccurate. We live in a fallen world where misfortune, sickness, and death are part of everyday life due to both human fallenness (Galatians 5:4) and the influence of Satan.

Bajju refrain from speaking about evil; to do so means that evil will happen. In this, they imply that through good intentions human beings can prevent all evil from occurring. Rather Jesus told us that,

The light has come into the world, and people who do evil things are judged guilty because they love the dark more than the light. ${ }^{2}$ People who do evil hate the light and won't come to the light, because it clearly shows what they have done. But everyone who lives by the truth will come to the light, because they want others to know that God is really the one doing what they do. (John 3:19-21, CEV).

Here Jesus clearly indicates that people love darkness, not light, and cannot of themselves prevent evil or misfortune through their own good intentions. Yet, if they live by the Truth, they can come to the light and allow God to work through them.

Bajju assign responsibility to nonconforming individuals for the misfortune of others and have no conception of an ultimate evil spirit. But scripture assigns final blame to Satan, the one who is the father of lies (John 8:44). Bajju do believe in evil spirits, some of whom cause problems for people and some of whom want to live their own lives without interference from humans. But they do not believe in an ultimate evil power, a situation which presented a problem when we and the translation team translated the New Testament into Jju, the Bajju language. We used katenyang, the word for one of the small spirits, for Satan. I have often thought that we should have used a phrase that translates as the "chief of the evil spirits" for Satan even though this is a new concept for them. In scripture Satan means the "accuser," and it would have made sense to the Bajju to view witchcraft accusations as likely coming from him.

As I have suggested above, witchcraft beliefs function to punish nonconforming or difficult people in the social arena. But Christianity does not encourage this kind of blaming. Teaching from passages such as I John 1:8-10 provides a way for people to take responsibility for their own failures by confessing their own sins and receiving God's forgiveness rather than accusing others. Even when others are guilty, taking revenge upon them is something Christians leave with the Lord. Jesus tells us to turn the other cheek (Matthew 5:39), to forgive multiple times (Matthew 18:20-22), to leave vengeance to him for he will repay (Romans 12:19), and to love our enemies, pray for them and treat them kindly (Matthew 5:44, Romans 12:20-21). Christians must love and forgive those who mistreat them (I Peter 4:12-19). ${ }^{3}$

I Corinthians 13 is a good place to start, with love being the guiding principle for relating to others. Convincing them to live in accordance with this passage would involve breaking the grip of belief in witchcraft within traditional culture and redirecting their thoughts and behavior to how Jesus would have us relate to one another. Jesus is able to do this through his Holy Spirit.

As a reminder, the Bible clearly forbids involvement in witchcraft in Deuteronomy 18:10 when Moses instructed the Israelites upon entering the land of Canaan,

Let no one be found among you who sacrifices his son or daughter in the fire, who practices divination or sorcery, interprets omens, engages in witchcraft, or casts spells, or who is a medium or spiritist or who consults the dead. (NIV)

Today some combine biblical with traditional beliefs to assert that an evil spirit enters a person whose spirit then works with other spirits in the spiritual realm

\footnotetext{
${ }^{3}$ Christians in northern Nigeria often assert that they have turned the other cheek and that they have no more cheeks to turn. In some ways this is a cop-out. There are other biblical passages that tell us to forgive our enemies seventy times seven (Matthew 18:2122) and to love our enemies and to pray for them (Matthew 5:44).
} 
to cause evil, misfortune, illness, and death. While evil spirits do enter people in the Bible, there are no accounts of people's spirits leaving their bodies to meet with other spirits. By asserting that evil spirits cause one's spirit to leave its body and meet with other spirits in the spiritual realm, Christians are seeking to Christianize witchcraft. Since pastors are in the position of spiritual leaders, people expect them to identify who is a witch. Thus, the church is sometimes involved in Christianizing witchcraft beliefs. I would encourage missionaries and local Christians to work together with Christ to break the hold of the use of witchcraft within African Christian cultures.

\section{Why has belief in witchcraft continued?}

In the beginning of missions to witchcraft-oriented cultures, many missionaries were blissfully unaware of this explanatory system. Part of the reason for their lack of awareness was the language they used in their work. Missionaries worked through the "language of wider communication," Hausa, with the result that many missionaries did not understand the local worldview. Hausa is a Chadic language within the Afro-Asiatic language family, while Jju is a Plateau language within the Benue Congo language family. Yet Hausa is the language of the church. The Bible and hymnbook Christians use in church services are all in Hausa. Both missionaries and local pastors asserted that "Everyone knows Hausa.” However, in 1984 when my research assistant and I administered an interview schedule, we found $69 \%$ of the respondents spoke Hausa at a market level or less (McKinney 1990). When missionaries did seek to address nkut, their use of Hausa interfered with communication of basic Christian principles and practices. The closest term for witchcraft in Hausa is dabo, which means magic, conjuring, sleight of hand, and trickery (Bargery 1934:176, Newman 1990:161). Clearly, dabo does not cover the same semantic domain as nkut does.

Some missionaries, who were aware of the use of witchcraft, taught that it was simply superstition that local Christians should ignore. Yet many Bajju Christians continue to feel that they must deal with it because it answers a different set of questions than Christianity does. For example, witchcraft answers questions such as why a particular person became ill and died; why an individual failed to obtain a job for which s/he was obviously qualified; why a student failed an exam when s/he had carefully studied the material; why a person was killed in an automobile accident at a particular location while others were not killed when driving past the same location, and so on.

Some missionaries evinced a certain amount of arrogance. They came with the answer, namely Christ. However, they failed to know the questions the local religion answered. So, Christianity became an overlay on the traditional religion, with the two systems coexisting and answering two different sets of questions. The work of the missionaries produced many people who identified with Christianity but failed to know Christ (see McKinney 1994). For Christianity to really be understood, it must be prepared to answer the same set of questions as the traditional religions.

Despite the incomplete communication that has taken place in the presentation of Christianity, a people movement to Christ has occurred. Yet, in one instance as I watched people enter the river for baptism, the question that continued to go through my mind was, "How much of the gospel do they really understand?" This was a valid question, especially in the light of their receiving the gospel in Hausa. The continued presence of witchcraft beliefs in Christian communities makes the point. In the case of the Bajju this is gradually changing as Bajju seminary students study the situation by writing biblical responses to questions such as, "Why do people become ill and die?” (Kunhiyop 1988).

Bajju live in the consciousness of God's presence. A frequently heard expression in daily conversation is "God exists/is present” (“Kaza an ssh»). This phrase indicates God's omniscience and omnipresence. I remember once when a Bajju man rode with us in our car on a trip to Kaduna. At one point we had two flat tires at the same time. Because one tire was incompletely repaired, it went flat every fifty kilometers, and we again pumped air into it. Each time our passenger stated, “God exists, we go!” (Kaza ən sshi, zi cong!). Beginning with this strong belief and experience of God's presence, and together with a translation of the Bible into their own mother tongue, Bajju Christians can redirect their understanding away from witchcraft beliefs toward a more biblical understanding of human fallenness and evil.

\section{References}

Asake, Musa Nchock. 1991. An Evaluation of the Historical Development of Christianity among the Bajju of Northern Nigeria with Special Emphasis on Selected Ethical-Doctrinal Tensions. Th.M. thesis submitted to Dallas Theological Seminary, Dallas TX.

Bargery, G.P. 1934. A Hausa-English Dictionary and English-Hausa Vocabulary. London: Oxford University Press.

Evans-Pritchard, E.E. 1976 (orig. 1937). Witchcraft Oracles and Magic among the Azande, abridged ed. Oxford: Clarendon Press.

Hill, Harriet. 1996. Witchcraft and the Gospel: Insights from Africa. Missiology XXIV (3):323-344.

Kaburuk, Chidawa. 1976. Polygyny in the Old Testament and the Church in Africa. M. of Sacred Theology thesis submitted to Dallas Theological Seminary, Dallas TX. 
Kato, Marcus Nkut. 1973. Kaje Death and Burial Ceremonies. Savanna 2:219-222.

—. 1974. A Study of Traditional Social Organization Among the Kaje with Reference to Social Change During the Recent Past. M.A. thesis submitted to Ahmadu Bello University, Zaria, Nigeria.

Kluckhohn, Clyde. 1967 (orig. 1944). Navaho Witchcraft. Boston: Beacon Press.

Kunhiyop, Samuel Waje. 1988. Developing the Christian Core Among the Bajju with Special Application to the Belief in Nkut. M.A. thesis submitted to Western Conservative Baptist Seminary, Portland OR.

Mbiti, John S. 1975. Introduction to African Religion. London: Heinemann.

McKinney, Carol V. 1985. The Bajju of Central Nigeria: A Case Study of Religious and Social Change. Ph.D. dissertation submitted to Southern Methodist University, Dallas TX.

—. 1990. Which Language: Trade or Minority? Missiology XVIII(3):279-290.

- 1994. Conversion to Christianity, A Bajju Case Study. Missiology XXII(2):147-165.

Newman, Roxana Ma. 1990. An English-Hausa Dictionary. New Haven: Yale University Press.

O'Donovan, Jr., Wilbur. 1992. Introduction to Biblical Christianity. Ilorin: Nigeria Evangelical Fellowship.

Offiong, Daniel. 1985. Witchcraft Among the Ibibio of Nigeria. In Magic, Witchcraft, and Religion, An Anthropological Study of the Supernatural. Arthur C. Lehmann and James E. Myers, edits. Pp. 152-165. Palo Alto: Mayfield Publishing Company. [Originally published in 1983, African Studies Review 26(1):107124.]

Tremearne, A.J.N. 1912. The Tailed Headhunters of Nigeria. London: Seeley, Service and Co.

Wilson, Monica. 1971. Religion and the Transformation of Society, A Study in Social Change in Africa. Cambridge: Cambridge University Press.
Carol McKinney, her late husband Norris, and their children moved to the Bajju village of Unguwar Rimi on December 26, 1968. Their goals were learning to speak, analyzing Jju, and translating the New Testament. The community welcomed them warmly as they were in the midst of a people movement to Christ. After the New Testament was completed, Carol earned her Ph.D. in anthropology from Southern Methodist University in Dallas, Texas. For her dissertation she went to Nigeria in 1983-1984 where she had a research fellowship with Ahmadu Bello University. Her goals were to research the Bajju adoption of Christianity. After returning to the U.S., she taught at the SIL School, which subsequently became the Graduate Institute of Applied Linguistics. She has also published Globe Trotting in Sandals, a book on ethnographic research methods, and co-authored with her husband Introduction to Field Phonetics.

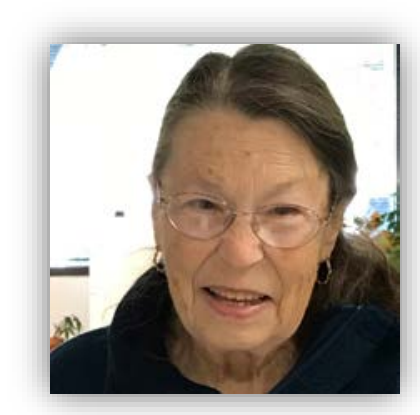

Author email: carol_mckinnev@gial.edu 